\title{
The Optimization of Corruption Deterrence during the Covid-19 Pandemic
}

\author{
Andi Hidayat Anugrah Ilahi", Yeni Widowaty** \\ DOI: https://doi.org/10.22304/pjih.v8n1.a4
}

Submitted: December 18, 2020 |Accepted: March 28, 2021

\begin{abstract}
During the Covid-19 Pandemic, weak monitoring and evaluation have opened greater opportunities for money laundering and, in general, corruption cases. The Indonesian Survey Institute revealed data, which exposes an increase of $39.6 \%$ of the public's perception regarding the scale of corruption cases during the pandemic. This survey is in line with the data of the Indonesian Corruption Watch mentioning 169 corruption cases during the first period of 2020. In the era of economic and health crises, corruption surely may provide greater impact and damage to the state governance and community activities. This study aims to measure the optimization of actual efforts to counter corruption during the Covid-19 Pandemic. It is a descriptive-qualitative with literature study to reveal facts. The method is in line with the use of information management activities carried out by formal and non-formal institutions during the Covid-19 pandemic. The target population is state institutions or government agencies that act as law enforcers to counter money laundering or, in general, corruption. The target population covers them who have specialization to operate tasks dealing with corruption crimes. The study shows that there have been many programs and synergies carried out by law enforcers and the government. However, they have not been able to mitigate and to eradicate corruption. Therefore, for the purpose of improvement, the parties need to adjust monitoring and evaluation system with the Covid-19 Pandemic conditions.
\end{abstract}

Keywords: corruption, covid-19 pandemic, optimization.

\section{Pencegahan Tindak Pidana Korupsi di era Pandemi Covid-19, Sudah Optimalkah?}

\begin{abstract}
Abstrak
Lemahnya monitoring dan evaluasi pada era pandemi covid-19 ternyata membuat tingginya peluang tindak pidana pencucian uang utamanya dari segi kasus korupsi. Signifikansi ini dibuktikan dari data Lembaga Survei Indonesia yang menunjukkan peningkatan sebanyak 39,6 \% dari persepsi masyarakat yang menyatakan tingginya kasus korupsi selama pandemi. Survei ini ternyata juga sejalan dengan data 169 kasus korupsi yang terjadi selama periode I tahun 2020 oleh Indonesian Corruption Watch. Tindak pidana korupsi yang terjadi pada era krisis ekonomi dan kesehatan selama pandemi covid telah merugikan aktivitas tata kelola negara dan masyarakat sehingga penelitian ini ingin mendalami bagaimana sebenarnya upaya pencegahan tindak pidana korupsi selama pandemi Covid-19,
\end{abstract}

PADJADJARAN Journal of Law Volume 8 Number 1 Year 2021 [ISSN 2460-1543] [e-ISSN 2442-9325]

* Magister Student of the Faculty of Law, Universitas Muhammadiyah Yogyakarta, Jl. Brawijaya, Kasihan, Bantul, Yogyakarta 55183, S.H. (Universitas Muhammadiyah Yogyakarta), andihidayat2911@gmail.com.

** Lectures of criminology of the Faculty of Law, Universitas Muhammadiyah Yogyakarta, Jl. Brawijaya, Kasihan, Bantul, Yogyakarta 55183, S.H. (Universitas Muhammadiyah Yogyakarta), yeniwidowaty@umy.ac.id. 
apakah telah optimal atau belum? Metode penelitian yang digunakan adalah deskriptif kualitatif dengan menggunakan studi pustaka untuk melihat fakta empiris di lapangan. Hal tersebut juga sejalan dengan pemanfaatan kegiatan pengelolaan informasi yang dilakukan oleh lembaga dan lembaga negara pada saat pandemi Covid-19. Populasi sasaran teoritis adalah lembaga negara atau lembaga pemerintah yang bertindak sebagai penegak hukum tindak pidana pencucian uang. Populasi sasaran operasional mengkhususkan diri pada divisi tertentu yang bertugas menangani kejahatan pencucian uang. Hasil studi menunjukkan bahwa sudah banyak program dan sinergi yang dilakukan oleh aparat penegak hukum dengan pemerintah namun belum mampu memitigasi dan memberantas tindak pidana pencucian uang secara keseluruhan. Oleh karena itu, perlu dilakukan pembenahan sistem monitoring dan evaluasi untuk beradaptasi dengan pandemi Covid-19.

Kata Kunci: covid-19, korupsi, optimalisasi.

\section{A. Introduction}

Money laundering is a serious transnational crime and possesses threats to states and societies. The crime may cause malfunction across multiple state institutions such as banks, financial service providers, as well as national and local governments. ${ }^{1}$ Money Laundering is defined in Article 1 paragraph 1 of the Law Number 8 of 2010 as any act that fulfills the elements of a criminal act in accordance with the laws. ${ }^{2}$ Sunaryadi defines money laundering as the process of shifting profits resulted from illegal activities into legal financial assets. ${ }^{3}$

The Law Number 8 of 2010 (Article 3) regulates sentences for money laundering. It especially mentions that anyone who places, transfers, spends, pays, donates, entrusts, takes abroad, changes forms, exchanges for currency or securities or other assets shall be punished for the crime of money laundering with a maximum imprisonment of twenty years and a maximum fine of ten billion rupiahs. ${ }^{4}$

The law confirms that Indonesia tries to prevent money laundering considering the effect to the economic stability and the financial integrity. Money laundering also endangers the foundations of society, nation, and state. Therefore, the penalties and fines are intended to provide deterrent effect. ${ }^{5}$ In addition, optimizing eradication and prevention of money laundering must be based on a convincing legal basis to ensure legal certainty, effectiveness of law enforcement, and efforts to return assets resulted from money laundering. ${ }^{6}$ The most common

\footnotetext{
Fransiska Novita Eleanora, "Tindak Pidana Pencucian Uang", Jurnal Hukum, Vol. 26, Issue 2, 2011, p. 640. Law Number 8 of 2010 on the Prevention and Eradication of Money Laundering.

Ahmad Yani, "Kejahatan Pencucian Uang (Money Laundering) (Tinjauan Undang-Undang Nomor 8 Tahun 2010 Tentang Pencegahan Dan Pemberantasan Tindak Pidana Pencucian Uang)", Widya Yustisia, Vol. 1, Issue 1, 2013, pp. 1-9. Article 3 of the Law Number 8 of 2010 on the Prevention and Eradication of Money Laundering. Ibid.

Law Number 8 of 2010 on the Prevention and Eradication of Money Laundering.
} 
type of money laundering in Indonesia is corruption in institutions and government.

Indonesia has recorded many money-laundering cases. In 2018, Indonesia was on $89^{\text {th }}$ position of 180 states according to the Corruption Perception Index (CPI). On the findings from the Indonesian Corruption Watch (ICW), during the first semester of 2020, there were 169 cases of Corruption with 139 new topics. ${ }^{7}$ The cases were found in various sectors ranging from village budgets, government, education, transportation, health, and worse, social assistance funds with different mapped modes such as mark up, budget abuse, embezzlement, fictional reports, bribery, illegal levies, etc. However, there is an interesting issue about the phenomenon of corruption cases in Indonesia. Based on a survey conducted by the Indonesian Survey Institute (LSI-Lembaga Survei Indonesia), there are $39.6 \%$ of respondents mentioning an increase in corruption cases in the last two years during the era of the Covid-19 pandemic (2019-2020). There are $13.8 \%$ respondents who agree that criminal acts of corruption decreased during the pandemic. On the contrary, $31.9 \%$ says nothing had changed, while $14.8 \%$ have no opinion. ${ }^{8}$ In conclusion, an issue suggests that corruption during the pandemic has increased, and this issue needs to be studied further.

Recently, the Corruption Eradication Commission (KPK-Komisi Pemberantasan Korupsi) conducted a silent operation to trace the Covid-19 Social Assistance fund. The case involved the Minister of Social Affairs of Indonesia, Juliari P. Batubara. The estimated state loss budget is IDR 677.2 trillion and the KPK arrested high-class officials of the Ministry of Social Affairs. ${ }^{9}$ Another case that draws attention is the case of lobster seeds exports involving Edhy Prabowo, the Minister of Marine Affairs and Fisheries. ${ }^{10}$

In addition to facing the Covid-19 pandemic, the Indonesian government also faces the challenge to solve corruption. Altogether, the government confronts three problems: (1) population health observation; (2) protection of the business sector; and (3) criminal handling. For example, Indonesia's unemployment has increased by 25 million in August. It consists of 10 million self-employed workers and 15 million casual workers. ${ }^{11}$ Furthermore, considering Indonesia's current

Indonesia Corruption Watch, "ICW: Ada 169 Kasus Korupsi Sepanjang Semester I 2020", https://nasional.kompas.com/read/2020/09/29/16112851/icw-ada-169-kasus-korupsi-sepanjang-semester-i2020, accessed on February 2021.

8 Liputan 6, "Survei LSI: Tren Korupsi Di Pandemi Covid-19 Diyakini Meningkat", https://www.liputan6.com/news/read/4398860/survei-Isi-tren-korupsi-di-pandemi-covid-19-diyakinimeningkat, accessed on February 2021.

9 Detik News, "Korupsi Bansos Yang Memalukan", https://news.detik.com/kolom/d-5286263/korupsi-bansosyang-memalukan, accessed on February 2021.

10 Ekonomi Bisnis, "Menteri Sosial Korupsi Dana Bansos, Pengamat: Ubah Jadi Cash Transfer", https://ekonomi.bisnis.com/read/20201206/9/1327139/menteri-sosial-korupsi-dana-bansos-pengamatubah-jadi-cash-transfer, accessed on December 2020.

11 Lembaga Ilmu Pengetahuan Indonesia, "Kriminalitas Di Era COVID-19 Dan Pekerja Muda", https://kependudukan.lipi.go.id/id/berita/53-mencatatcovid19/942-kriminalitas-di-era-covid-19-dan-pekerjamuda, accessed on November 2020. 
condition with a shortage in terms of economic, social, and security stability, the state officials should have a more significant responsibility in handling each sector.

Law enforcement officers play a substantial role in preventing and enforcing laws, especially in corruption crimes during the Covid-19 pandemic. The legal actors are expected to optimally anticipate emergencies of corruption and money laundering during the Covid-19 pandemic. Corruption opportunity comes from several factors, including the fund allocation from the central government to fight the pandemic situation and high levels of layoffs due to economic instability, which result high unemployment levels. ${ }^{12}$ However, this situation actually could be prevented with a synergy of laws and institutions to monitor, evaluate, and sentence. This study examined the optimization of the handling and the prevention of corruption and money laundering cases, as well as challenges and obstacles experienced by state institutions in Indonesia during the Covid-19 pandemic ${ }^{13}$.

This study employed literature study and descriptive approach. The literature review of the study explains theories, findings, and other materials to form the foundation. The literature review is an up-to-date information on corruption cases and challenges during the Covid-19 pandemic. This research is relevant and adequate to add knowledge on case studies of corruption during the Covid-19 pandemic. The results compiled detailed data on several mitigation facts and efforts to eradicate corruption during the Covid-19 pandemic. The study used primary data consisting of the Law Number 8 of 2010. The study also used secondary legal sources, which are additional data in the forms of books, the internet, theses, and sources. The data collection process was carried through literature search, namely by discussing and analyzing. The data analysis system used content analysis from the implications of regional regulations, programs, and other law enforcement officials' efforts together with several regulations on corruption.

\section{B. Theoretical Study of the Causes of Corruption During The Covid-19 Pandemic}

Pellegrini put forward a functionalist theory that corruption can emerge in a place if there is an institutional vacuum and a social function service that is unsatisfying. On the other hand, the actors of corruption are not punished. ${ }^{14}$ Huntington further supports the theory that the only thing that is the worst of a society is a rigid, too centralized, and dishonest bureaucracy. ${ }^{15}$

The theories explain major corruption cases in Indonesia. One of them involved the Minister of Maritime Affairs and Fisheries, Edhi Prabowo, causing state losses

12 Pesmin Alvianis and Yida Sekti Purnomo, "Tinjauan Hukum Terhadap Virus Korona, Pemecatan Pegawai Dan Korupsi", LawArXiv Papers, Vol. 2, Issue 2, 2020, p. 1.

Judy Mikovits, Kents Heckenlively, Plague of Corruption, New York: Skyhorse, 2021, p. 36.

Lorenzo Pellegrini, Corruption, Environment and Development, The Hague: Springer US, 2011, p. 35.

Ibid, p.45. 
of up to IDR 7.9 billion in November $2020 .{ }^{16}$ The rigid and centralized bureaucracy in the cooperation of the central ministry with third parties is reflected in the monopoly of PT ACK company as the only exporter of lobster seeds at the cost of 1800 birds per transport. ${ }^{17}$ The KPK alleged that Edhy Prabowo received a fee from the director of PT Dua Putra Perkasa (PT DPP) for 100,000 US dollars and received a fix for the lobster seed export license of 3.4 billion. ${ }^{18}$ The centralized command and control of the central ministry in carrying out ministry programs develops a high chance of corruption cases in Indonesia. ${ }^{19}$

The high opportunity for corruption is also not without reason. Pellegrini's idea is that institutional vacancies are also factors causing the emergence of acts of corruption. An institutional vacuum in an organization is generally defined as a government actor who has lost control of the organization, and no one has replaced the actor. Another opinion says that the institutional vacuum is a central authority identify and other forces. Other actors will tend to "rush" to fill the void. In the future, there are two possibilities: whether the successor is a highly credible or vice versa. ${ }^{20}$ Otherwise, this power vacuum is reflected in President Joko Widodo cabinet reshuffle in 2019 from Susi Pudjiatusi to Edhy Prabowo as minister of maritime affairs and fisheries. During Widodo's administration, the cabinet had been reshuffled several times. This may slow down the performance of ministries because new officers have to adapt and start performance from zero to maintain a balance between economic growth and political stability. ${ }^{21}$

Additionally, the lobster seeds corruption case is a reflection of Pellegrini's idea about social functions that were never sufficient externally and internally. The internal factor is determined as a human sociological urge appearing to perform despicable acts to fulfill human desires that will never reach the point of sufficient. ${ }^{22}$ The external factors are the social functions of government institutions or systems that are not satisfied in gaining benefits. In the case of lobster seed, there is institutional dissatisfaction in managing Indonesia's maritime wealth to be traded. Lobster seeds will be more beneficial if they are optimized for domestic

16 Kompas, "Kasus Suap Ekspor Benih Lobster, KPK Dalami Pemberian Uang Kepada Edhy Prabowo", https://nasional.kompas.com/read/2021/01/08/14080081/kasus-suap-ekspor-benih-lobster-kpk-dalamipemberian-uang-kepada-edhy, accessed on February 2021.

17 Kompas, "Kasus Suap Izin Ekspor Bibit Lobster, KPK Panggil Staf Edhy Prabowo", https://nasional.kompas.com/read/2020/12/07/11103571/kasus-suap-izin-ekspor-bibit-lobster-kpk-panggilstaf-edhy-prabowo, accessed on February 2021.

18 Ibid.

19 Jenny Job (et.al), "Culture Change in Three Taxation Administrations: From Command-and-Control to Responsive Regulation", Law and Policy, Vol. 29, Issue 1, 2007, pp. 84-101.

20 Joseph Yinka Fashagba, "De-Constitutionalising? Democratic Governance in Nigeria: Assessing ExecutiveLegislative Handling of Executive-Power Vacuum in the Fourth Republic", Africana: A Journal of Ideas on Africa and the African Diaspora, Vol. 4, Issue 1, 2010, p. 250.

21 Universitas Muhammadiyah Yogyakarta, "Kontroversi Reshuffle Kabinet Indonesia Maju, Apa Sebenarnya Strategi Jokowi?", https://www.umy.ac.id/kontroversi-reshuffle-kabinet-indonesia-maju-apa-sebenarnyastrategi-jokowi.html, accessed on February 2021.

22 Lorenzo Pellegrini, op.cit., p. 23. 
Indonesian cultivation, according to the Pusat Kajian Maritim Indonesia (Indonesian Maritime Studies Center)..$^{23}$

Law enforcement in Indonesia further complicates the corruption case. It takes a long time to punish perpetrators of corruption. Sometimes, the perpetrators are not punished at all or only have light sentences, and not under their violation of the law. For example, the threats of the Chairperson of KPK, Firli Bahuri, to them who are red-handedly caught stealing social assistance fund. ${ }^{24}$

Until now, the words are only words. There is no single perpetrator who is sentenced to death. Article 2 paragraph 2 of the Law Number 31 of 1999 on Corruption Crime reads as follows: ${ }^{25}$

"Koruptor dapat dihukum mati jika perbuatannya dilakukan pada waktu negara dalam keadaan bahaya nasional dan bencana nasional." [Corruptor can be sentenced to death if the deed is performed when the state is in a condition of national danger or/and national disaster.]

Jack Bologne's theory (GONE) describes the case involving the Minister of Social Affairs, Juliari P. Batubara, that there are four main factors causing corruption as follows.

$$
G=\text { Greedy } \quad O=\text { opportunity } \quad N=\text { Needs } \quad E=\text { Expose }
$$

Greedy $(G)$ is related to the greed of the perpetrator who commits corruption crimes. Opportunity (O) supports this nature. ${ }^{26}$ Opportunities occur in time and place gaps enabling the potential corruptor to take personal or group benefits with taking the social fund for the poor who have difficulties during the pandemic. Several government officers obtain the gaps in corruption due to the direct appointment mechanism in managing social funds. ${ }^{27}$ The goal is to facilitate program implementation in times of crisis and help the people to face the economic crisis. However, the lack of monitoring and supervision makes corruption activity efficiently carried out. Furthermore, Needs (N) show the human desire that is never satisfied to meet daily needs. The last, Expose (E) is related closely to the

23 Republika, "Ekspor Benih Lobster Yang Bermasalah Dari Hulu Ke Hilir", https://republika.co.id/berita/nasional/news-analysis/qklqfx328/ekspor-benih-lobster-yang-bermasalah-darihulu-ke-hilir, accessed on February 2021.

24 CNN Indonesia, "Korupsi Bansos Corona Dan Ancaman Hukuman Mati Dari KPK", https://www.cnnindonesia.com/nasional/20201207091312-12-578758/korupsi-bansos-corona-danancaman-hukuman-mati-dari-kpk, accessed on February 2021.

25 Article 2 of the Law Number 31 of 1999 on Corruption Eradication.

26 Glory Augusta Elisabeth Mangaranap Sianipar and Lilis Ardini, "Pemeriksaan Keuangan Negara Pada Masa Pandemi COVID-19”, Jurnal Sekuritas (Saham, Ekonomi, Keuangan Dan Investasi), Vol. 4, Issue 1, 2020, p. 34.

27 Kompas, "Korupsi Bansos Ini Jangat Jahat...", https://www.kompas.com/tren/read/2020/12/06/143500765/korupsi-bansos-ini-sangat-jahat?page=all, accessed on February 2021. 
realm of law that does not touch the corruptors, so they tend to repeat their actions. $^{28}$

Another theory of the cause of corruption is Klitgaard's that formulates the following equation. ${ }^{29}$

$$
\text { "C }=\mathbf{M}+\mathrm{D} \text { â€” } A
$$

$C=$ Corruption $M=$ Monopoly of Power $D=$ Discretion of official $A=$ Accountability"

A centralized monopoly (M) of power held by the Minister of Social Affairs is added with discretion (D) of a person. Juliari P. Batubara is a minister or highest leader with great power to manage the state revenue and expenditure budget in the ministry of social affairs. Minimal and limited accountability $(A)$ occurs due to the situation during the pandemic. ${ }^{30}$ The government-shifting phenomenon is a shift from ordinary government institution to good government system consisting of civil society, governance, and private actors. It has ultimately resulted in a new framework of power-advocacy system. ${ }^{31}$ The relationship between corruption and power advocacy is based on certain officers' closeness or interest to gain mutual benefit. This phenomenon is represented in the collaboration of three echelon officials from the Ministry of Social Affairs with social assistance vendors for IDR 12 billion and 8.8 billion from the October-December 2020 to fulfill Juliari P. Batubara's personal needs. ${ }^{32}$

The last theory that the author uses in seeing the phenomenon of corruption during the Covid-19 pandemic is the Vroom Theory as follows. ${ }^{33}$

$$
\begin{gathered}
\mathbf{M}=\mathbf{f}(\mathbf{E}, \mathbf{V}) \\
M=\text { Motivation } E=\text { Expectation } V=\text { Valance } / \text { Value }
\end{gathered}
$$

A corruptor's motivation (M) is generated from expectations $(E)$ and $(V)$ values. The values can be in social, legal, and integrity norms shaping the corruptor's identity. For example, suppose the holder of power has a value of integrity. In that case, if he tends to do good practices or activity with high or low expectations in his vision. Vice versa, if the expectations and values are negative, the motivation to commit corruption increases based on deviant practices. ${ }^{34}$

28 Direktorat Jenderal Pemasyarakatan, "Teori-Teori Korupsi-Ditjenpas", http://ditjenpas.go.id/teori-teorikorupsi, accessed on February 2021.

Ibid.

Ibid.

31 Metodi Sotirov and Georg Winkel, "Toward a Cognitive Theory of Shifting Coalitions and Policy Change: Linking the Advocacy Coalition Framework and Cultural Theory", Policy Sciences, Vol. 49, Issue 2, 2016, pp. 125-154.

32 Ekonomi Bisnis, "Kronologi Mensos Juliari Kena OTT KPK Akibat Korupsi Dana Bansos Covid-19", https://ekonomi.bisnis.com/read/20201206/12/1326944/kronologi-mensos-juliari-kena-ott-kpk-akibatkorupsi-dana bansos-covid-19, accessed on February 2021.

33 Direktorat Jenderal Pemasyarakatan, op.cit.

34 Bambang Waluyo, "Optimalisasi Pemberantasan Korupsi Di Indonesia Bambang Waluyo Kejaksaan Agung Republik Indonesia Email”, Jurnal Yuridis, Vol. 1, Issue 2, 2014, pp. 169-182. 
Juliari P. Batubara's motivation was ruined by public report. ${ }^{35}$ The report is categorized as 'extraneous variables' that affect the expectations (E) of the perpetrator of corruption who have motivation $(\mathrm{M})$ to commit the crime of corruption. The KPK receives public information based on a receipt of money from private sector to government administrator (commitment-makers and program official at the Ministry of Social Affairs). ${ }^{36}$ A total of IDR 14.5 billion (IDR 11.9 billion), or about USD 171.085 (equivalent to Rp.2.420 billion) and approximately 23,000 Singapore dollars (equal to IDR 243 million) were stored in suitcases, backpacks, and envelopes and handed over in an apartment in Jakarta. ${ }^{37}$

\section{Analysis of the Stakeholders Function in Law Enforcement Efforts Before The Covid-19 Pandemic}

Indonesia implements anticorruption institutions' governance, which aims to synergize and effectively enforce law. ${ }^{38}$ The institution's governance is strictly regulated to gain the checks and balances system based on the Law Number 30 of 2002 on the Corruption Eradication Commission. The law affirms that the main institution tasked to carry out investigations is the KPK. The KPK handle the task of corruption eradication, while the Indonesian National Police and other institutions take over other duties and functions. The objective of the job allocation is to avoid overlapping authorities of law enforcement agencies dealing with corruption. ${ }^{39}$

Since the implementation of the law, the KPK handles the corruption eradication and prevention. Its performance has been more optimal. The optimization can be seen from the relations to the imposition of illegal compensation money, criminal fines (including illegal subsidies, confiscation of property, and funds flow) from corruption to be traced, blocked, and frozen. ${ }^{40}$ According to Article 74 of the Law Number 8 of 2010, the KPK has the authority to investigate money laundering.

"Penyidikan tindak pidana pencucian uang dilakukan oleh penyidik tindak pidana asal sesuai dengan ketentuan hukum acara dan ketentuan peraturan perundang undangan, kecuali ditentukan lain menurut undang undang ini".

35 Kompas, "Berawal Dari Laporan Masyarakat, Begini Kronologi OTT Dugaan Suap Bansos Covid-19 Di Kemensos", https://nasional.kompas.com/read/2020/12/06/02531141/berawal-dari-laporan-masyarakatbegini-kronologi-ott-dugaan-suap-bansos?page=all, accessed on February 2021.

36 Ibid.

37 Pikiran Rakyat, "Perjalanan Kasus Menteri Sosial, Dari Pengadaan Bansos Corona, OTT, Hingga Jadi Tersangka", https://www.pikiran-rakyat.com/nasional/pr-011069680/perjalanan-kasus-menteri-sosial-daripengadaan-bansos-corona-ott-hingga-jadi-tersangka, accessed on February 2021.

38 Herry Susilowoti, Laporan Penelitian Tata Kelola Lembaga Penegak Hukum Tindak Pidana Korupsi Di Indonesia, 2012 Perjanjian No: III/LPPM/2012-09/77-P LAPORAN.

39 Law Number 31 of 1999 on regarding the Eradication of Criminal Acts of Corruption.

40 Emerson and Donal Fariz Febri, Penguatan Pemberantasan Korupsi Melalui Fungsi Koordinasi Dan Supervisi Komisi Pemberantasan Korupsi, Jakarta: Indonesia Corruption Watch, 2011, p. 35. 
[Money laundering investigations shall be carried out by investigators following provisions of the procedural law and other regulations unless otherwise stipulated by this law"]

The explanation of Article 74 states that investigator is an official from an agency authorized by law to carry out investigations. They are the Indonesian National Police, the Attorney General Office, the Corruption Eradication Commission (KPK), the National Narcotics Agency (BNN), and the Directorate General of Customs and Excise of the Ministry of Finance.

The Police has different authority with the KPK. However, they have the authority to carry out investigations on corruption. ${ }^{41}$ The investigation covers corruption cases that do not involve law enforcement officials or state officials and cause state losses of up to IDR 1,000,000,000 (one billion rupiahs) and other issues delegated the KPK. ${ }^{42}$ Police Investigator is police officers who are authorized by law to carry out investigations. They have the authority to search for and find an incident categorized as a special criminal act (corruption, collusion, and nepotism) for the determination of further investigations according to article 1 point 5 of the Indonesian Criminal Law.

The Indonesian National Police delegate corruption cases investigation to the Sub-Directorate for Economic and Special Crimes at the Criminal Investigation Unit. The Directorate of Special Criminal Investigation in each Regional Police is the direct subsidiary. They have the Sub-Directorate for Action ${ }^{43}$ handling money laundering and banking crimes, as well as corruption in general. The eradication of money laundering brings implication, the increase of financial intelligence information in corruption eradication and the settlement of corruption case files transferred to the Public Prosecutor. ${ }^{44}$

Another law enforcement institution that has an authority to investigate is the Attorney, based on Article 74 of the Money Laundering Law. The law regulates that Money laundering investigations shall be carried out by investigators following provisions of the procedural law and other regulations. An investigator may investigate money laundering if the investigator finds sufficient preliminary evidence of money laundering while investigating the predicate crime.

41 Tribata News, "Peran Polri Dalam Berantas Tindak Pidana Pencucian Uang", https://tribratanews.kepri.polri.go.id/2019/01/07/peran-polri-dalam-berantas-tindak-pidana-pencucianuang/, accessed on November 2020.

42 Sabrina Hidayat, "Tinjauan Yuridis Kewenangan Komisi Pemberantasan Korupsi Melakukan Penyidikan Penggabungan Perkara Tindak Pidana Korupsi Dan Pencucian Uang Legal Analysis the Power of Corruption Eradication Commission on Investigation of Case Combination on Corruption", Halu Oleo Law Review, Vol. 1, Issue 2, 2017, pp. 180-195.

43 Junaidi Abdullah, "Tugas Dan Wewenang Lembaga- Lembaga Penanganan Tindak Pidana Korupsi Di Indonesia", Yudisia, Vol. 5, Issue 1, 2014, pp. 102-122.

44 Simon Butt, Corruption and Law in Indonesia, Jakarta: Routledge Contemporary Southeast Asia Series, 2017, p. 76. 
The indictments filed by public prosecutor for money laundering are generally cumulative because predicate crime and money laundering crime are different. Perpetrator of predicate crime carries out the locus of the modus operandi. In terms of evidence, based on the Law Number 8 of 2010, it should be easier to prove the prosecution of money laundering. According to Article 73 of the Law Number 8 of 2010, the evidence of money laundering includes the testimony of witnesses, experts, letters, instructions, and statements of the defendant (Article 184 of the Criminal Procedure Code), as well as other evidence in the form of information uttered, sent, received, or stored electronically with optical or similar devices and documents.

The Attorney General Office must be fair in prosecuting punishment to corruptors because the office is a law enforcement agency in the final stages of investigation. In carrying out the duties, the Attorney General Office is supervised by the Prosecutorial Commission ${ }^{45}$ based on Article 38 of Law Number 16 of 2004 on the Attorney General Office. To improve the performance of the Attorney General Office, the President can form a prosecutorial commission. The President regulates the composition and the authority.

Apart from law enforcement, several institutions are authorized to carry out mitigation. The Financial Transaction Analysis Reporting Center (PPATK-Pusat Pelaporan Analisis Transaksi Keuangan) plays a significant role in the communication and coordination mechanisms between agencies involved in efforts to enforce the anti-money laundering regime in Indonesia. The PPATK is responsible to the President directly. The PPATK oblige the party reporting Financial Service Providers (PJK - Penyedia Jasa Keuangan) to submit three types of reports, they are:(1) Suspicious Financial Transaction Reports (LTKM -Laporan Transaksi Keuangan yang Mencurigakan); and (2) Cash Financial Transaction Reports (LTKT -Laporan Transaksi Keuangan Tunai), and International Fund Transfer Instruction. ${ }^{46}$

Furthermore, Article 41 states that the PPATK has the authority to: ${ }^{47}(1)$ request and get data and information from government agencies/or private institutions that have the authority to manage data and information, including from government agencies and private institutions that receive reports from certain professions; (2) establish guidelines for the identification of Suspicious Financial Transactions; (3) coordinate efforts to prevent money laundering with related agencies; (4) provide recommendations to the government regarding efforts to prevent money laundering; (5) represent the Republic of Indonesia in international organizations and forums related to the prevention and eradication of money

45 Ratnia Sholihah and Triono, "Peran KPK Dalam Mengawal Pengalokasian", Tapis: Teropong Aspirasi Politik Islam, Vol. 16, Issue 2, 2020, p. 69.

46 Della Destafri Kusher, "Fungsi Pusat Pelaporan Dan Analisis Transaksi Keuangan (PPATK) Dalam Melacak Transaksi Keuangan Yang Mencurigakan”, Lex Crimen, Vol. 4, Issue 4, 2015, pp. 5-9.

47 Law Number 8 of 2010 on Prevention and Eradication of the Criminal Act of Money Laundering. 
laundering; (6) organize anti-money laundering education and training programs; and (7) organize the socialization of prevention and eradication of money laundering.

Another institution is the Supreme Audit Agency (BPK-Badan Pemeriksa Keuangan), which has functions in the management, supervision, and accountability of state finances as stated in Article 1 paragraph 1 of the Law Number 15 of 2006 on the Supreme Audit Agency. Every institution, either in national and regional levels, and company provide financial reports to the BPK every year. Financial irregularity mechanism will be reported from the regional representative of BPK to the Central BPK, then to law enforcement officials (police, KPK, and the attorney general office) as a form of mitigation to rescue state finances. ${ }^{48}$

\section{Prevention and Eradication of Corruption by Related Institution during The Covid-19 Pandemic}

All law enforcement and mitigation agencies can collaboratively monitor and prevent corruption. However, during the pandemic, they experienced a setback. The coordination among institutions to prevent and eradicate money laundering originates from corruption have been established prior to the pandemic, although it only consists of few small programs. Some of the activities carried out include strengthening synergy between the KPK and the PPATK, collaborative visits between PPATK in handling the money laundering. This visit aims to increase the synergy that has been established, especially in terms of optimizing the handling of corruption cases.

The KPK synergizes with the PPATK to carry out systematic and integrated handling starting from the system of legislation, supervision, money tracing, and prosecution. The PPATK and the KPK will further intensify the handling of money laundering generated from corruption as an essential part to provide a punishment effect for the perpetrator and a deterrent effect for the potential perpetrator. ${ }^{49}$ The two institutions, which were founded in the reform era, have established close synergies in various disclosures of corruption and money laundering cases. Both have a commitment to strengthen the anti-money laundering spirit in every case. ${ }^{50}$ During the Covid-19 pandemic, the PPATK increase digital reports through the GRIPS application to facilitate the reporting system by means of digital progress. This is in line with the significant changes to the office system due to the pandemic. The application is available on the Google Playstore and not available on the Apple's Apps Store.

\footnotetext{
48 Rahmy Putri Yulia (et.al), "Peranan BPK Dan BPKP Menghitung Kerugian Keuangan Negara Dalam Rangka Penanganan Perkara Tindak Pidana Korupsi”, Jurnal Bina Adhyaksa, Vol. 6, Issue 2, 2016, pp. 135-152.

49 Toetik Rahayuningsih, "Analisis Peran Ppatk Sebagai Salah Satu Lembaga Dalam Menanggulangi Money Laundering di Indonesia", Yuridika, Vol. 28, Issue 3, 2013, pp. 314-330.

50 Pejabat Pengelola dan Penyimpan Informasi, "Tingkatkan Pengenaan Pasal TPPU, PPATK Perkuat Sinergi Dengan KPK", http://ppid.ppatk.go.id/?p=1074, accessed on November 2020.
} 
In addition, sharing of knowledge on the Prevention and Eradication of money laundering was actively carried out at Bank Indonesia Regional Representative Offices during the Covid-19 pandemic. This activity intends the local government stakeholders to understand the current challenges and dynamics related to antimoney laundering and corruption prevention. There is still a lot of preparation in the banking industry that supports the state's integrity in the form of bank report to the PPATK. ${ }^{51}$

The quality of the news must be continuously improved. There are still many findings that must be reported but not reported. On the other hand, things that cannot be reported is written. Undoubtedly this is a signal that must be resolved immediately, by both the banking industry and the PPATK. ${ }^{52}$

Various strategic works are being carried out. They include assessing the risk of APUPPT in the sectoral and individual scope, improving the quality of compliance audits, mapping financial integrity ratings in the form of the Financial Integrity Rating (FIR) documents, improving the reporting system, and Combating the Professional Existence of Money Laundering (PML). ${ }^{53}$ It is different with the KPK as the primary institution enforcing law. The KPK has fifteen clusters in escort and five cluster units to monitor and supervise social assistance funds or other funds that are used as budget transfers to disaster emergencies ${ }^{54}$.

The KPK monitored government activities, and budget transfers carried out by ministries and institutions to procure emergency goods and services. This program is based on collaboration with other institutions such as BPKP, PKPP, APIP, which are also engaged in supervising local government. ${ }^{55}$ The KPK identifies three vulnerable points for misappropriation of the state budget. They are, among others,

(1) Procurement of government goods and services;

(2) Grants for Covid-19 units or local governments;

(3) provision of social assistance in the form of kickbacks, markups, and conflicts of interest and fraud.

The KPK also has launched an application during the pandemic to report findings in social assistance funds. The application is named "JAGA BANSOS". The application aims to be a two-way information platform from public to the KPK as an informal supervisor in the field. On the other side, the Police recently are really busy improving the public services, which have been distracted by the Covid-19 pandemic. The Indonesian National Police and the Ministry of Administrative and

\footnotetext{
51 Fiona Suwana, "What Motivates Digital Activism? The Case of the Save KPK Movement in Indonesia", Information Communication and Society, Vol. 23, Issue 9, 2020, pp. 1295-1310.

52 Rusmin and Alistair M. Brown, "Indonesian Stakeholder Viewpoints of Indonesia's Anti-Money Laundering Legislation", Journal of Money Laundering Control, Vol. 11, Issue 3, 2008, p.261-268.

53 Lisanawati Go and Njoto Benarkah, "Quo Vadis Legal Profession Participation in Anti-Money Laundering", Journal of Money Laundering Control, Vol. 22, Issue 4, 2019, pp. 764-769.

54 Triono, op.cit., p.77.

55 lbid.
} 
Bureaucratic Reform are working together to accelerate the improvement of excellent service quality of the Police. ${ }^{56}$

The BPK is also trying to optimize its function during the Covid-19 pandemic, considering that the government has allocated a large part of the budget to the emergency Covid-19. The allocation is prone to fraud and corruption. ${ }^{57}$ The BPK's optimization during the Covid-19 pandemic aims to improve coordination and communication with the parties being examined based on the Law Number 15 of 2004 on Audit Management and Accountability of State Finances. During the Covid19 pandemic, the BPK examination is still based on the state financial audit standard (SPKN-Standar Pemeriksaan Keuangan Negara). It continues to carry out alternative procedures by optimizing technology and information in the work environment or working from home. Based on the law, the BPK can obtain financial management documents and data directly. Still, due to work from home (WFH) situation, the request is late. The BPK conducts coordination in advance to facilitate the process of auditing financial statements. ${ }^{58}$ In addition, the BPK uses video conferencing for financial management audits supported by the use of electronic documents. ${ }^{59}$

Some of these mitigation efforts have produced results. One of them is a public report to the KPK. During the Covid-19 pandemic, the KPK can carry out a silent operation. However, in line with the synergy of programs implemented by corruption mitigation and law enforcement agencies, the fact remains that the control set back during 2020. This setback is evidenced by the KPK's weakness. Even though a cluster unit has been formed, there are gaps for corruption, such as the social assistance corruption case involving Juliari P. Batubara. The success of KPK in arresting the minister through an operation is a reward during the pandemic. There are still many criminal law violations committed by government officials under that have not been touched and further studied.

For example, in the distribution of types and quantities of medical material equipment, such as Personal Protective Equipment (PPE), masks, hazmat sets, PCR machines. There is an unequal gap between demand and realization. ${ }^{60}$ Problems found in social assistance such as cuts/reductions of funds distribution in targeting social assistance recipients. The social fund was not following the needs, the social funds allocated to the wrong people, even the worst, the distribution of social

\footnotetext{
56 Kementerian Pendayagunaan Aparatur Negara, "Kementerian Pendayagunaan Aparatur Negara Dan Reformasi Birokrasi", https://www.menpan.go.id/site/berita-terkini/upaya-pembinaan-pelayanan-kepolisiandi-masa-pandemi, accessed on February 2021.

57 Rizki Zakariya, "Optimalisasi Pemeriksaan Laporan Keuangan Negara Oleh Badan Pemeriksa Keuangan Pada Masa Pandemi COVID-19", Jurnal Pajak dan Keuangan Negara, Vol. 2, Issue 1, 2020, pp. 112-113. Ibid. Ibid.

60 Indonesia for Global Justice, "Cerita Dari Pelosok Negeri: Problematika Penyaluran Bantuan Sosial Pemerintah Dalam Penanganan Covid 19 \& Pemulihan Ekonomi Di Masyarakat", https://igj.or.id/cerita-dari-pelosoknegeri-problematika-penyaluran-bantuan-sosial-pemerintah-dalam-penanganan-covid19-pemulihanekonomi-di-masyarakat/, accessed on February 2021.
} 
service to the dead people. ${ }^{61}$ To conclude, this was not fulfilling the vision or target. ${ }^{62}$ The invalidity and up-to-date Integrated Social Welfare Data as the basis for providing social funds for the victim of Covid-19 are conditions that must be solved immediately. From the ICW monitoring results, there were 239 complaints against social service distribution in 13 regions in Indonesia. ${ }^{63}$

The ICW has studied a set of data in December 2020 concerning the gaps for the corruption. The data consists of the Mineral and Coal Law, Government Regulation In Lieu of the Law Number 1 of 2020/Law Number 2 of 2020 to Handle Covid-19, and the Omnibus Law, which is closely related to political and business elitist interests. ${ }^{64}$ In fact, during the Covid-19 pandemic, the KPK lost its identity due to the revision of the Corruption Eradication Commission Law Number 19 of 2019 that revising the KPK's position to be under the executive level and destroying the internal corruption enforcement system by the KPK. From 2019 to 2020, apart from facing the pandemic, the KPK also does not have much power to overturn laws that have the potential to become corrupt practices. ${ }^{65}$

Law enforcement stakeholders have carried out several strategies. However, this is only base on strengthening each other's primary duties and functions. The PPATK Digital Report that all society levels can use has not been appropriately used due to its ignorance. ${ }^{66}$ Into the bargain, in general, corruption cases are pragmatic, rigid, and carried out by rulers so that the general public or government staff who have the intention to report the crime of money laundering in an agency are prone to incoming problems ${ }^{67}$

Furthermore, knowledge sharing between local governments and law enforcement officials helps minimize money laundering in regional government organizations. This program substantially affects the deterrent effect and psychological effects that can be categorized as internal factors. It will also make the local governments aware of law enforcement agencies' position, especially

61 BBC News, "Ekonomi Pandemi: Penyaluran Bantuan Sosial Ke Orang Yang Sudah Meninggal, Skema Kebijakan Dinilai tidak Tepat Sasaran", https://www.bbc.com/indonesia/indonesia-52399147, accessed on February 2021.

62 Kompas, "Melihat Efektivitas 9 Bantuan Dan Subsidi Pemerintah Selama 6 Bulan Pandemi", https://nasional.kompas.com/read/2020/09/03/12090061/melihat-efektivitas-9-bantuan-dan-subsidipemerintah-selama-6-bulan-pandemi?page=all, accessed on February 2021.

63 Ombudsman, "Bantuan Pemerintah di Masa Covid-19", https://ombudsman.go.id/artikel/r/artikel--bantuanpemerintah-di-masa-covid-19, accessed on February 2021.

64 Indonesia Corruption Watch, "Catatan Akhir Tahun Pemberantasan Korupsi Tahun 2020: Pandemi, Kemunduran Demokrasi, dan Redupnya Spirit Pemberantasan Korupsi", https://antikorupsi.org/id/article/catatan-akhir-tahun-pemberantasan-korupsi-tahun-2020-pandemikemunduran-demokrasi-dan, accessed on February 2021.

65 Nehru dan Adam Setiawan Asyikin, “Kedudukan Kpk Dalam Sistem Ketatanegaraan Pasca Diterbitkannya Revisi Undang-Undang KPK", Justitia Jurnal Hukum, Vol. 4, Issue 1, 2020, pp. 126-147.

66 Republika, "Cegah Pencucian Uang, PPATK Rilis Aplikasi Pelaporan Terbaru", https://www.republika.co.id/berita/qnu1q1383/cegah-pencucian-uang-ppatk-rilis-aplikasi-pelaporanterbaru, accessed on February 2021.

67 Robert I. Rotberg, The Corruption Cure : How Citizens and Leaders Can Combat Graft, Princeton: Princeton University Press, 2017, p. 55. 
those related to corruption. On top, this study categorizes an external factor in the form of an integrated audit system. This system will improve the reporting system and other authorities such as banking as a corruption tracker. Finally, the government and bank authority can synergize well. There is no opportunity to do the corruption or other money laundering crimes easily eradicated at the Indonesian government's regional level.

The BPK still needs to utilize information technology optimally. There is still lack of daily use of electronic reports such as Computer Assisted Audit Techniques (TABK). The big data analytics are listed in the BPK inspection guidelines in the Covid-19 situation or other state of disaster called ISSAI $5500^{68}$. The emergence of various regulations to fight the Covid-19 pandemic has led to the phenomenon of inadequate supervision due to limitations in BPK's movement and performance. The situation has generated low accountability and abuse of authority as in the case of lobster corruption. ${ }^{69}$

The law enforcement officers, especially the police, have increasingly heavy tasks. In addition to carrying out public services, the police carry out three functions of preventive, preemptive, and law enforcement. ${ }^{70}$ Currently they perform the preventive efforts by issuing circular letters to carry out preventive activities of the coronavirus's spread within the work unit, the preemptive actions by carrying out patrols and raids, and law enforcement efforts related to criminal offenses. It is different from the office of prosecutor, which has taken digital steps in conducting video conferences, and there is no separate plan in corruption mitigation. The three law enforcement institutions (the Police, the Attorney General, and the Corruption Eradication Commission) experienced a setback during the pandemic because law enforcement has not been the main agenda during the pandemic and no additional policy. ${ }^{71}$

The law enforcement officials can monitor and anticipate rigid and regimes in Indonesia if there is an integrated system and communication that is more open in the future. A good governance system is an excellent opportunity for civil society, state, business, and Academics. Furthermore, law enforcement officials that are capable in the eradication and mitigation of money laundering should be more able to explain the existence and real performance outside of the main tasks and functions to the people. Mitigation forms during the Covid-19 pandemic must be carried out in a brand-new system to prevent corruption in the future. Since the Covid-19 pandemic has not end yet, law enforcement officials have a big task and

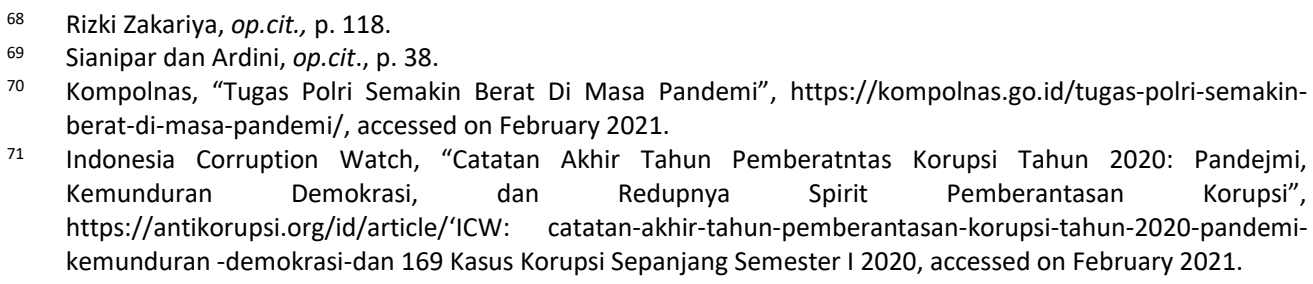
https://antikorupsi.org/id/article/'ICW: catatan-akhir-tahun-pemberantasan-korupsi-tahun-2020-pandemikemunduran -demokrasi-dan 169 Kasus Korupsi Sepanjang Semester I 2020, accessed on February 2021. 
responsibility to handle the corruption problem as well as other transnational crimes during the Covid-19 pandemic.

\section{E. Conclusions}

Indonesian law-enforcement officials face serious challenges in the mitigation and prevention of corruption. The Government has implemented many reform programs to anticipate the crime. However, the latest cases show that the programs have not generated satisfactory outcomes to reduce corruption, as well as other crime acts. In addition to the organization's internal performance, the synergy among agencies, monitoring, and evaluation of the stakeholders, such as the Financial Transaction Reports and Analysis Center (PPATK), needs to be included in an integrated system. The integrated system aims to minimize the forms of unofficial flows of funds by the government, which can be the proceeds of corruption.

The Covid-19 pandemic has changed the system of state structure significantly. The open system will be minimal since the work system in several institutions of government, as well as informal sector (such as the market and company), has imposed minimum office hours and the work from home system. The new system brings the expectation that law enforcement officials change the work system, adapting to formal and informal institutions. Therefore, the organization is not seen as a pseudo-organization that loses its identity in the new era. It is necessary for law enforcement officials in every institution to act in the new system optimally. Therefore, the causes of corruption and money laundering crimes can be prevented.

Into the bargain, the public control is also important to create a smart, developing, and dynamic society during the pandemic. People must continue to remain present in creating synergistic surveillance that has been success revealing several cases of corruption in Indonesia. It is another big challenge for the law enforcement officials considering that the new climate is challenging during the pandemic. Nevertheless, public participation schemes will assist the law enforcement officials in carrying out their duties significantly. The presence of technology that is very close to people's lives can provide immediate access to participation. Then, the mitigation can be implemented. The problem should be a focus for all levels of society to eradicate corruption and other crime acts. There is no single group in the social order that support corruption practice considering that there have been many losses and disasters resulted. Full participation and synergy of law enforcement officials in government agencies must be established, especially during the Covid-19 pandemic.

\section{References}

\section{Books}

Butt, Simon, Corruption and Law in Indonesia, Routledge Contemporary Southeast 
Asia Series, Jakarta, 2017.

Emerson, Febri and Donal Fariz, Penguatan Pemberantasan Korupsi Melalui Fungsi Koordinasi dan Supervisi Komisi Pemberantasan Korupsi, Indonesia Corruption Watch, Jakarta, 2011.

Mikovits, Judy and Kents Heckenlively, Plague of Corruption, Skyhorse, New York, 2021.

Pellegrini, Lorenzo Corruption, Environment and Development, Springer, Hague, 2011.

Rotberg, Robert I., The Corruption Cure : How Citizens and Leaders Can Combat Graft, Princeton University Press, Princeton, 2017.

\section{Other Documents}

Ahmad Yani, "Kejahatan Pencucian Uang (Money Laundering) (Tinjauan UndangUndang Nomor 8 Tahun 2010 Tentang Pencegahan dan Pemberantasan Tindak Pidana Pencucian Uang)", Widya Yustisia, Vol. 1, Issue 1, 2013.

Bambang Waluyo, "Optimalisasi Pemberantasan Korupsi di Indonesia Bambang Waluyo Kejaksaan Agung Republik Indonesia Email", Jurnal Yuridis, Vol. 1, Issue 2, 2014.

BBC, "Ekonomi Pandemi: Penyaluran Bantuan Sosial ke Orang yang Sudah Meninggal, Skema Kebijakan Dinilai tidak Tepat Sasaran", https://www.bbc.com/indonesia/indonesia-52399147.

CNN, "Korupsi Bansos Corona Dan Ancaman Hukuman Mati Dari KPK", https://www.cnnindonesia.com/nasional/20201207091312-12-

578758/korupsi-bansos-corona-dan-ancaman-hukuman-mati-dari-kpk.

Della Destafri Kusher, "Fungsi Pusat Pelaporan Dan Analisis Transaksi Keuangan (PPATK) dalam Melacak Transaksi Keuangan Yang Mencurigakan", Lex Crimen, Vol. 4, Issue 4, 2015.

Detik News, "Korupsi Bansos Yang Memalukan", https://news.detik.com/kolom/d5286263/korupsi-bansos-yang-memalukan.

Direktorat Jenderal Permasyarakatan, "Teori-Teori Korupsi", http://ditjenpas.go.id/teori-teori-korupsi.

Ekonomi Bisnis, "Kronologi Mensos Juliari Kena OTT KPK Akibat Korupsi Dana Bansos

Covid-19", https://ekonomi.bisnis.com/read/20201206/12/1326944/kronologi-mensosjuliari-kena-ott-kpk-akibat-korupsi-dana-bansos-covid-19.

Ekonomi Bisnis, "Menteri Sosial Korupsi Dana Bansos, Pengamat: Ubah Jadi Cash Transfer" <https://ekonomi.bisnis.com/read/20201206/9/1327139/menterisosial-korupsi-dana-bansos-pengamat-ubah-jadi-cash-transfer.

Fashagba, Joseph Yinka, "De-Constitutionalising? Democratic Governance in Nigeria: Assessing Executive-Legislative Handling of Executive-Power Vacuum in 
the Fourth Republic", Africana: A Journal of Ideas on Africa and the African Diaspora, Vol. 4, Issue 1, 2010.

Fiona Suwana, "What Motivates Digital Activism? The Case of the Save KPK Movement in Indonesia", Information Communication and Society, Vol. 23, Issue 9, 2020.

Fransiska Novita Eleanora, "Tindak Pidana Pencucian Uang", Jurnal Hukum, Vol. 26, Issue 2, 1970.

Glory Augusta Elisabeth Mangaranap Sianipar, and Lilis Ardini, "Pemeriksaan Keuangan Negara Pada Masa Pandemi COVID-19", Jurnal Sekuritas, Vol. 4, Issue $1,2020$.

Herry Susilowoti, Laporan Penelitian Tata Kelola Lembaga Penegak Hukum Tindak Pidana Korupsi di Indonesia, 2012.

Indonesia Corruption Watch, "Catatan Akhir Tahun Pemberantasan Korupsi Tahun 2020: Pandemi, Kemunduran Demokrasi, dan Redupnya Spirit Pemberantasan Korupsi", $\quad$ https://antikorupsi.org/id/article/catatan-akhir-tahunpemberantasan-korupsi-tahun-2020-pandemi-kemunduran-demokrasi-danRedupnya-Spirit-Pemberantasan-Korupsi.

Indonesia Global Justice, "Cerita Dari Pelosok Negeri: “Problematika Penyaluran Bantuan Sosial Pemerintah Dalam Penanganan Covid-19 \& Pemulihan Ekonomi Di Masyarakat", https://igj.or.id/cerita-dari-pelosok-negeri-problematikapenyaluran-bantuan-sosial-pemerintah-dalam-penanganan-covid19pemulihan-ekonomi-di-masyarakat.

Job, Jenny, Andrew Stout, and Rachael Smith, "Culture Change in Three Taxation Administrations: From Command-and-Control to Responsive Regulation", Law and Policy, Vol. 29, Issue 1, 2007.

Junaidi Abdullah, "Tugas Dan Wewenang Lembaga- Lembaga Penanganan Tindak Pidana Korupsi Di Indonesia", Yudisia, Vol. 5, Issue 1, 2014.

Kementrian Pendayagunaan Aparatur Negara, "Kementerian Pendayagunaan Aparatur Negara Dan Reformasi Birokrasi", https://www.menpan.go.id/site/berita-terkini/upaya-pembinaan-pelayanankepolisian-di-masa-pandemi.

Kompas, "Berawal Dari Laporan Masyarakat, Begini Kronologi OTT Dugaan Suap Bansos Covid", https://nasional.kompas.com/read/2020/12/06/02531141/berawal-darilaporan-masyarakat-begini-kronologi-ott-dugaan-suap-bansos?page=all.

"ICW: Ada 169 Kasus Korupsi Sepanjang Semester I 2020", https://nasional.kompas.com/read/2020/09/29/16112851/icw-ada-169-kasuskorupsi-sepanjang-semester-i-2020. 
, "Kasus Suap Ekspor Benih Lobster, KPK Dalami Pemberian Uang Kepada Edhy Prabowo", https://nasional.kompas.com/read/2021/01/08/14080081/kasus-suap-eksporbenih-lobster-kpk-dalami-pemberian-uang-kepada-edhy.

, "Kasus Suap Izin Ekspor Bibit Lobster, KPK Panggil Staf Edhy Prabowo", "https://nasional.kompas.com/read/2020/12/07/11103571/kasus-suap-izinekspor-bibit-lobster-kpk-panggil-staf-edhy-prabowo".

, "Melihat Efektivitas 9 Bantuan dan Subsidi Pemerintah Selama 6 Bulan Pandemi..",

https://nasional.kompas.com/read/2020/09/03/12090061/melihat-efektivitas9-bantuan-dan-subsidi-pemerintah-selama-6-bulan-pandemi?page=all.

"Korupsi Bansos Ini Sangat Jahat...",
https://www.kompas.com/tren/read/2020/12/06/143500765/korupsi-bansosini-sangat-jahat?page=all.

Kompolnas, "Tugas Polri Semakin Berat Di Masa Pandemi", https://kompolnas.go.id/tugas-polri-semakin-berat-di-masa-pandemi.

LIPI, "Kriminalitas Di Era COVID-19 Dan Pekerja Muda", https://kependudukan.lipi.go.id/id/berita/53-mencatatcovid19/942kriminalitas-di-era-covid-19-dan-pekerja-muda.

Liputan 6, "Survei LSI: Tren Korupsi Di Pandemi Covid-19 Diyakini Meningkat", https://www.liputan6.com/news/read/4398860/survei-Isi-tren-korupsi-dipandemi-covid-19-diyakini-meningkat.

Lisanawati Go and Njoto Benarkah, "Quo Vadis Legal Profession Participation in Anti-Money Laundering", Journal of Money Laundering Control, Vol. 22, Issue 4, 2019.

Metodi Sotirov and Georg Winkel, "Toward a Cognitive Theory of Shifting Coalitions and Policy Change: Linking the Advocacy Coalition Framework and Cultural Theory", Policy Sciences, Vol. 49, Issue 2, 2016.

Nehru Asyikin and Adam Setiawan, "Kedudukan Kpk Dalam Sistem Ketatanegaraan Pasca Diterbitkannya Revisi Undang-Undang KPK", Justitia Jurnal Hukum, Vol. 4, Issue 1, 2020.

Ombudsman, "Bantuan Pemerintah di masa Covid-19", https://ombudsman.go.id/artikel/r/artikel--bantuan-pemerintah-di-masacovid-19.

Pesmin Alvianis and Yida Sekti Purnomo, "Tinjauan Hukum Terhadap Virus Korona, Pemecatan Pegawai Dan Korupsi", LawArXiv Papers, Vol. 2, Issue 2, 2020.

Pikiran Rakyat, "Perjalanan Kasus Menteri Sosial, Dari Pengadaan Bansos Corona, OTT, Hingga Jadi Tersangka", https://www.pikiran-rakyat.com/nasional/pr- 
011069680/perjalanan-kasus-menteri-sosial-dari-pengadaan-bansos-coronaott-hingga-jadi-tersangka.

PPATK, "Tingkatkan Pengenaan Pasal TPPU, PPATK Perkuat Sinergi Dengan KPK", http://ppid.ppatk.go.id/?p=1074.

Rahmy Putri Yulia, A Khunaefi, and Suryadi Agoes, "Peranan BPK Dan BPKP Menghitung Kerugian Keuangan Negara Dalam Rangka Penanganan Perkara Tindak Pidana Korupsi", Jurnal Bina Adhyaksa, Vol. 6, Issue 2, 2016.

Republika, "Cegah Pencucian Uang, PPATK Rilis Aplikasi Pelaporan Terbaru", https://www.republika.co.id/berita/qnu1q1383/cegah-pencucian-uang-ppatkrilis-aplikasi-pelaporan-terbaru.

"Ekspor Benih Lobster Yang Bermasalah Dari Hulu Ke Hilir", https://republika.co.id/berita/nasional/news-analysis/qklqfx328/ekspor-benihlobster-yang-bermasalah-dari-hulu-ke-hilir.

Rizki Zakariya, "Optimalisasi Pemeriksaan Laporan Keuangan Negara Oleh Badan Pemeriksa Keuangan Pada Masa Pandemi COVID-19", Jurnal Pajak Dan Keuangan Negara, Vol.2, Issue 1 , 2020.

Rusmin and Alistair M. Brown, "Indonesian Stakeholder Viewpoints of Indonesia's Anti-Money Laundering Legislation", Journal of Money Laundering Control, Vol. 11, Issue 3, 2008.

Sabrina Hidayat, "Tinjauan Yuridis Kewenangan Komisi Pemberantasan Korupsi Melakukan Penyidikan Penggabungan Perkara Tindak Pidana Korupsi Dan Pencucian Uang Legal Analysis the Power of Corruption Eradication Commission on Investigation of Case Combination on Corruption An", Halu Oleo Law Review, Vol.1, Issue 2, 2017.

Toetik Rahayuningsih, "Analisis Peran PPATK Sebagai Salah Satu Lembaga Dalam Menanggulangi Money Laundering Di Indonesia", Yuridika, Vol. 28, Issue 3, 2013.

Tribata News, "Peran Polri Dalam Berantas Tindak Pidana Pencucian Uang", https://tribratanews.kepri.polri.go.id/2019/01/07/peran-polri-dalam-berantastindak-pidana-pencucian-uang/.

Triono and Ratnia Sholihah, "Peran Kpk Dalam Mengawal Pengalokasian", Tapis: Teropong Aspirasi Politik Islam, Vol. 16, Issue 2, 2020.

Universitas Muhammadiyah Yogyakarta, "Kontroversi Reshuffle Kabinet Indonesia Maju, Apa Sebenarnya Strategi Jokowi?", https://www.umy.ac.id/kontroversireshuffle-kabinet-indonesia-maju-apa-sebenarnya-strategi-jokowi.html.

\section{Legal Documents}

Law Number 8 of 2010 on the Prevention and Eradication of the Criminal Act of Money Laundering [Undang-Undang Nomor 8 Tahun 2010 tentang Pencegahan 
dan Pemberantasan Tindak Pidana Pencucian Uang].

Law Number 31 of 1999 on Corruption Eradication [Undang-Undang Nomor 31 tahun 1999 tentang Pemberantasan Tindak Pidana Korupsi].

Law Number 30 of 2002 on Corruption Eradication [Undang-Undang Nomor 30 Tahun 2002 tentang Komisi Pemberantasan Korupsi]. 